\title{
Optimal packaging for food products is an effective solution to save resources and minimize the environmental impact
}

\section{Oleksandr Gavva, Nataliya Kulyk National University of Food Technologies, Kyiv, Ukraine}

\begin{abstract}
An analytical and calculation approach to the optimal packaging choice based on the rating of importance of various factors has been developed to ensure the balance of packaging functions, such as: proper preservation of the packaged product during shelf life, product safety for consumption, efficient use of resources. Based on the analysis of the most important factors, such as: the properties of the packaged product, its shelf life, the possible interaction between the product and packaging material, the optimal mass of the filled goods, as well as economic and environmental factors, the approach to choice optimal packaging for certain food product has been proposed. The optimal packaging is selected based on the comparison of total scores calculated for different packages. Total score is the sum of all evaluated requirements. Each requirement value is a result of multiplication of the degree of conformity of the package to a specific requirement in comparison with other types of packaging analyzed and rating of importance of a certain requirement.

As an example the analysis and comparison of different packaging for milk. The optimal packaging was considered the pillow bag with the "total score" equal to 2 when other packaging types had lower total scores.

Such an approach can ensure the economic competitiveness of a packaged product on the market and minimize environmental impact by preventing product losses and minimizing of the recourses for packaging production and recycling.
\end{abstract}

Keywords: packaging, food, milk, recycling.

Corresponding author: Nataliya Kulyk

E-mail: nataliya.kulyk@ukr.net

DOI: 10.24263/RES-2019-13

\section{Introduction}

One of the most important problems in a rapidly growing planet population is the availability of adequate quality and safety food [11]. Another acute problem is the depletion of the resources needed to meet the needs of humanity [10,11]. Human activity leads not only to a reduction of resources, but also to a negative impact on the environment. According to the FAO World Food and Nutrition Status Report 2017, a hunger affected 815 million people (11\% of the world population) in 2017 [11].

At the same time, annually around the world, around 30 to $50 \%$ of food is wasted, which is about 1.3 billion tons. In 2014, food losses in Europe reached more that 100 
million tones. In 2020, it will be around 120 million tones (+20\%) unless the situation changes.[12]

The role of packaging in food preservation is difficult to overestimate. To solve these problems, it is important to use the optimal packaging that will save the packaged products, but at the lowest cost of its production and recycling. Food products have a higher value than the packaging for them protection [10,12].

Thus, the loss of food products because of inefficient packaging may have a more negative result in for rational use of resources and impact on the environment. Also over costs of manufacturing and recycling the packaging could not be considered justified.

\section{Materials and methods}

Materials. Different types of milk packaging:

- Pillow bag produced from polyethylene film;

- $\quad$ Tetra Pack produced from combined material such as: cardboard / Alu foil / PE;

- $\quad$ Bottle produced from rigid polyethylene plastic [3,8]

Methods. The analytical and calculation approach to the choice of optimal packaging, taking into account the rating of importance of various factors [2].

\section{Results and discussion}

The basic properties of the products and the factors which are important for choosing a optimal packaging solution have been analyzed. An analytical and calculation approach to the optimal packaging choice has been proposed, taking into account the rating of importance of various factors.

The concept of "optimal packaging" or "optimal packaging design" corresponds to the balance between providing all the packaging functions for a certain foodstuff and the cost of manufacturing and recycling it after use [1,3]. Optimal packaging is packaging that is good enough for a certain product, taking into account the shelf life and conditions of storage. Figure 1 shows the scheme for determining the optimal packaging design [9]. 
Resource and Energy Saving Technologies of Production and Packing of Food Products as the Main Fundamentals of Their Competitiveness: Proceedings of the 8th International Specialized Scientific and Practical Conference, September 12, 2019. Kyiv, Ukraine

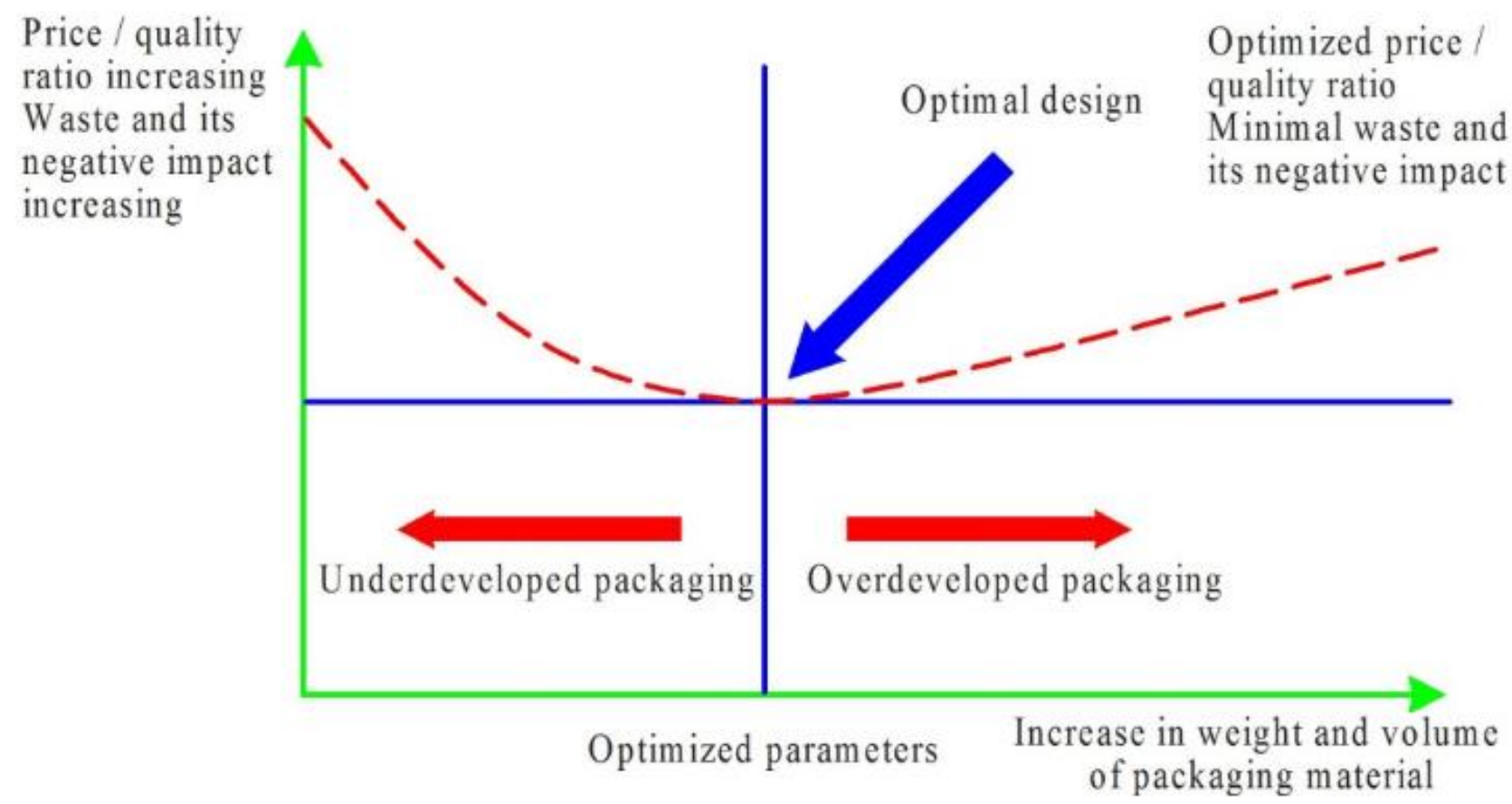

Figure 1. Optimal packaging design

Packaging optimization begins with the choice of the proper material and the size of the packaging. The product's properties and safety is a priority factor that cannot be neglected or compromised. The following basic product features and logistical factors must be considered to determine and select the optimal packaging for a particular product $[4,5]$ :

- Packed product properties (aggregate condition, composition, packaging conditions and subsequent processing of the packed product (temperature, pressure, humidity, time, etc.));

- Shelf life of the packaged product to be provided, storage and transportation conditions; analysis of potential risks and factors of impact on the product during transportation and storage;

- Possible interaction between the product and the internal environment as well as packaging material, minimizing such interaction is ensured by the correct selection of the packaging structure, the technology of its production and packaging;

- The optimum weight of the packaged product on the basis of determination of the potential consumer group of a certain product, rational norms and terms of its consumption;

- Economic analysis: the choice of the optimal packaging solution for a certain product in order to provide all the technical requirements with the minimum consumption of resources;

- Environmentally friendly packaging solution: recyclability, loss of product prevention due to proper protection during the shelf life, packaging safety for the product and ensuring $100 \%$ product consumption. 
The packaging must correspond to the composition and properties of the packaged products to preserve them. In evaluating the packaging complex, the following components should be taken into account: the packaged product, the internal environment in the packaging above the product, the packaging material, the external environment into the packaging. (Figure 2) [6].

To ensure the protection of food products from changes in their composition and properties it is necessary to choose the optimal packaging based on the analysis of the product properties and processes that occur during storage and transportation of packed food goods, as follows: (Figure 2).

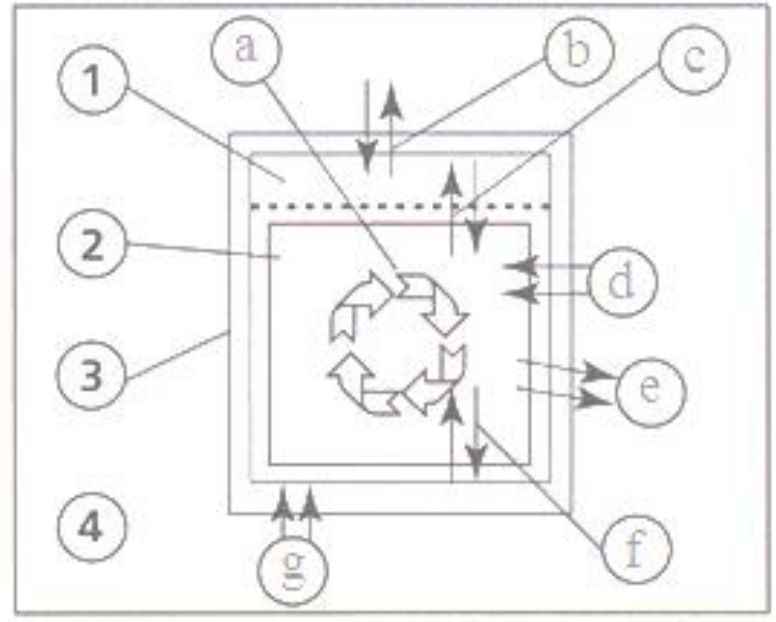

Figure 2. Processes in packaging complex

a - biochemical processes in the product;

$\mathrm{b}$ - interaction between the internal and external environment;

$\mathrm{c}$ - interaction between the product and the internal microenvironment;

$\mathrm{d}$ - penetration of liquids, vapors, gases, sunlight and other outside influences

e - product loss;

$\mathrm{e}$ - interaction between the product and the packaging material;

$\mathrm{g}$ - the influence of the environment on the packaging material.

1 - internal environment in the packaging above the product;

2 - packaged product;

3 - packaging material;

4 - external environment.

The analytical and calculation approach to the choice of optimal packaging, taking into account the rating of importance of various factors, can be demonstrated by the example of choosing the optimal packaging for milk [7]. The approach includes two steps: the first is the analysis of the different types of packaging (Table 1), the second one is the calculation of the rating taking into account the importance of different requirements (Table 2). 
Resource and Energy Saving Technologies of Production and Packing of Food Products as the Main Fundamentals of Their Competitiveness: Proceedings of the 8th International Specialized Scientific and Practical Conference, September 12, 2019. Kyiv, Ukraine

Table 1

Analysis of different types of milk packaging

\begin{tabular}{|c|c|c|c|}
\hline Characteristics & Packaging 1 & Packaging 2 & Packaging 3 \\
\hline $\begin{array}{l}\text { Quality deterioration } \\
\text { processes }\end{array}$ & \multicolumn{3}{|c|}{ Oxidation, clotting, growth of microorganisms } \\
\hline $\begin{array}{l}\text { The main factors of } \\
\text { influence }\end{array}$ & \multicolumn{3}{|c|}{ Oxygen, temperature, impurities, raw materials } \\
\hline $\begin{array}{l}\text { Type of packaging } \\
\text { (package, bottle, jar, box, } \\
\text { etc.) }\end{array}$ & Pillow bag & Tetra Pack & Bottle \\
\hline $\begin{array}{l}\text { Packaging material } \\
\text { (paper, polymer film, } \\
\text { combined flexible } \\
\text { material, cardboard, tin, } \\
\text { glass, etc.) }\end{array}$ & $\mathrm{PE}^{*}$ film & $\begin{array}{l}\text { Combined material } \\
\text { cardboard / Alu foil } \\
\text { / PE }\end{array}$ & PE, rigid plastic \\
\hline Advantages & $\begin{array}{l}\text { Low packaging } \\
\text { weight, } \\
\text { recyclable } \\
\text { packaging, } \\
\text { lowest cost }\end{array}$ & $\begin{array}{l}\text { The medium weight } \\
\text { of the package, the } \\
\text { packaging provides } \\
\text { a long shelf life }\end{array}$ & $\begin{array}{l}\text { The packaging } \\
\text { can be recycled, } \\
\text { easy to use, } \\
\text { reclosed }\end{array}$ \\
\hline Disadvantages & $\begin{array}{l}\text { The packaging is } \\
\text { sensitive to } \\
\text { mechanical } \\
\text { damage, not very } \\
\text { convenient to use }\end{array}$ & $\begin{array}{l}\text { Recycling } \\
\text { packaging with } \\
\text { the combined } \\
\text { material is not cost- } \\
\text { effective, the } \\
\text { highest cost }\end{array}$ & $\begin{array}{l}\text { The largest weight } \\
\text { of the packaging }\end{array}$ \\
\hline
\end{tabular}

*PE-polyethylene

Food manufacturers can add and / or modify the list of packaging requirements, as well as the importance of rating the importance of those requirements, taking into account the characteristics of their product, technical and economic objectives. This approach facilitates the selection of the optimal packaging for a certain product and makes it possible to provide clear arguments for such a choice to be discussed by a group of interested professionals and to make a packaging decision that will guarantee the safe storage of the product for the required time, product safety for consumption and efficient and economical use of resources.

This will ensure the economic competitiveness of the packaged product on the market and minimize environmental impact through the prevention of product losses and the minimum use of resources for packaging production with a view to its recycling. 
Resource and Energy Saving Technologies of Production and Packing of Food Products as the Main Fundamentals of Their Competitiveness: Proceedings of the 8th International Specialized Scientific and Practical Conference, September 12, 2019. Kyiv, Ukraine

Table 2

Rating calculation based on the importance of different requirements

\begin{tabular}{|l|l|c|c|c|c|}
\hline No & Requirements & Rating, R & Packaging 1 & Packaging 2 & Packaging 3 \\
\hline 1 & $\begin{array}{l}\text { Packaging response } \\
\text { requires the } \\
\text { preservation and } \\
\text { safety of the } \\
\text { products }\end{array}$ & 0,4 & $1 \times 0,4=0,4$ & $3 \times 0,4=1,2$ & $2 \times 0,4=0,8$ \\
\hline 2 & Economic efficiency & 0,3 & $3 \times 0,3=0,9$ & $1 \times 0,3=0,3$ & $2 \times 0,3=0,4$ \\
\hline 3 & $\begin{array}{l}\text { Environmental } \\
\text { impact }\end{array}$ & 0,2 & $3 \times 0,2=0,6$ & $1 \times 0,2=0,2$ & $2 \times 0,2=0,4$ \\
\hline 4 & $\begin{array}{l}\text { Convenience } \\
\text { for use }\end{array}$ & 0,1 & $1 \times 0,1=0,1$ & $2 \times 0,1=0,2$ & $3 \times 0,1=0,3$ \\
\hline & $\begin{array}{l}\text { Total score* } \\
\Sigma, \text { points }\end{array}$ & 2,0 & 1,9 & 1,9 \\
\hline
\end{tabular}

* The total score is the sum of points when evaluating all the requirements by the formula: $\Sigma=\mathrm{L} \times \mathrm{R}$

where, $\mathrm{L}$ is the degree of conformity of the package to a specific requirement in comparison with other types of packaging analyzed ( 1 - the lowest level, 3 - the highest level)

$\mathrm{R}$ - rating of importance of a certain requirement (the sum should be equal to 1) or weight factor.

The packaging that has the highest score can be considered optimal.

\section{Conclusions}

1. The global problem of today is the loss of food products, which account for more than $30 \%$. Food waste does more harm to the environment than packaging waste.

2. Packaging is an important component and an integral part of the food industry. The packaging saves more resources than is spent on its production, preventing the formation of food waste. Choosing the best packaging based on an analytical and computational approach is an effective solution for the rational use of resources and the minimization of environmental impact.

\section{References}

1. Neil Farmer (2013), Trends in packaging of food, beverages and other fastmoving consumer goods. Markets, materials and technologies, Wood Publishing Limited.

2. Jim Peters, Brian Higgins, Michael Richmond (2013), Creating Value Through Packaging, Packaging technologies Integrated Solutions, Lancaster. 
Resource and Energy Saving Technologies of Production and Packing of Food Products as the Main Fundamentals of Their Competitiveness: Proceedings of the 8th International Specialized Scientific and Practical Conference, September 12, 2019. Kyiv, Ukraine

3. Jung H. Han (2014), Innovations in Food Packaging, PepsiCo Corporate R\&D/PepsiCo advanced Research, Plano.

4. Nnamdi Anyadike (2003), Introduction to Flexible Packaging, Pira International Ltd..

5. Coles R., McDowell D., Kirwan M.J. (2004), Food Packaging Technology, Boca Raton.

6. Joseph F. Hanlon, Robert J. Kelsey, Hallie Forcinio (1998), Handbook of Package Engineering, CRC Press.

7. Nerlita M. Manalili, Moises A. Dorado, Robert van Otterdijk (2011), Appropriate packaging solutions for developing countries, FAO, Rome.

8. Khalaiji V.V., Krivoshey V.N. (2018), Food and beverage packaging, Kyiv.

9. Laurence McKeen (2015), Film properties of plastics and elastomers,

1. Film Properties of Plastics and Elastomers. 4th Edition, Elsevier

10. Available at: https://www.flexpack-europe.org/en/

11. Available at: http://www.fao.org/home/en/

12. Available at: https://www.save-food.org/ 